\title{
Sending Flowers to the Moon: Notes on Flowers and Writing
}

Short, delicate, heady breaths. I disappear into the bouquet on my desk of white flowers-white flowers in winter, white flowers longing to become snow. All the other memory-short senses are utterly, magnificently dreary beside this one. And yet, the language of flowers is woeful - their fragrant gestures are feeble; no sooner are they uttered than they droop and die. Still, the old, elusive language of flowers is more accurate than our own.

$*$

\section{Knowledge.}

What do we know that a flower cannot say? What does a flower know that we cannot? What has not been said about flowers, said with flowers? Every rose knows roses, speaks of past roses, quotations spelled out in red, pink, yellow dust.

What does the muse know of flowers? In a poem called "Envoi," Eavan Boland writes:

The winter-flowering jasmine casts a shadow

outside my window in my neighbor's garden.

These are the things that my muse must know.

Perhaps the muse, a woman's muse, is a small and plain, speckled bird. Or, maybe, a bumblebee. Attracted by bowls of sugar water, pots of geraniums left on desks, trompe-l'oeil paintings of intricate bouquets.

\section{Necessity.}

"On my desk, small pink roses...When I am alone the flowers are really seen; I can pay attention to them. They are felt as presences. Without them I would die." (May Sarton).

The writer has a room of her own, she has food in her belly. Now she needs bunches of flowers in her rooms. Flowers decorating the stanzas of her poems. Vines growing up over the windows,

"It's a tangled world of vines, syllables, honeysuckle, colors, and words..." (Clarice Lispector).

Flowers on top of words on top of flowers. They perish and perish. Are renewed. A flower moves through time, because we crave something beautiful, alive. Because beauty isn't just one thing. We watch flowers bloom and peak, and wither and wilt and brown and droop and sag, lose petals and decay. Watching them perish, we learn how to live, which is the same as learning to write. 
Failure.

Flowers are about failure and so is writing. To fail so perfectly, as irrepressibly as a rose, is the writer's dream, a dream of a burning rose bush.

"What makes a work of art go from being good to great: the presence of doubt. It is not something directly spoken in the narrative; it is a thing you feel when you are in the presence of the text. Like a vague scent of blossom somewhere. The sorrow of knowing at the last moment you have failed" (Kristjana Gunnars). And still, the rose fails more completely, more sorrowfully, more subtly than any writing, any work of art. The writer competes with the rose, the begonia, the common daisy and is sure to lose. Fail again. Again. Fail. Writers need only compete with flowers.

$*$

\section{Beautiful Suffering.}

Phyllis Webb, in her essay, "Imaginations Companion" on flower imagery in Sharon Thesen's poetry says, "yes, they seem to suffer, as the poet does." She quotes Thesen's "Evocations":

...The

painful yellow tulips

open \& open \& open.

It's true, the writer is a flower, a yellow tulip, if you like. So vulnerable! Their fame, so transitory, so uncertain, so unlikely. Why be a writer? You might just as soon ask, why be a yellow tulip?

(If it is beautiful suffering, then is it suffering?)

(Shall I cross off "Beautiful" or "Suffering?")

$*$

\section{Death.}

"Everything ends with flowers." (Helene Cixous).

I have always just written my last poem, certain I will be diagnosed with terminal cancer, or one of the thousands of diseases that can kill you as quickly as any flower dies. Every poem is a flower, more or less beautiful than other flowers. Most fragrant right after I have written it. Then it fades, for me anyway, it fades. I press it in a book, forget it ever existed. When I come back to it later it is so very much less than it was. But I remember the beauty of forgotten things so well.

Who shall, I wanted to ask, offer flowers to the death

of flowers... . (E.D. Blodgett) 
To write is to attend funerals, place bouquets, wreaths and garlands at the graves of daisy chains and pockets full of posies and corsages. It is a tiring and difficult business, but there are always sandwiches, cookies and coffee afterwards. Sometimes a decent glass of sherry. You are so bloody thankful to be alive when you depart.

$*$

Sending flowers.

To write is to send flowers to the moon. To our dream-selves. To distant magical cities, to the thresholds of strangers. To lovers and to friends, yes, even to enemies. Bouquets of blooms, cut fresh from the unruly garden. How or whether they will be received is unknown. Or if they will be seen, truly seen, at all. Some arrangements will be more spectacular than others. But think, you have sent them...flowers to the moon.

Shawna Lemay 